\title{
PENANGANAN PERIOPERATIF ANESTESI PADA RESEKSI FEOKROMOSITOMA
}

\author{
Mordekhai L. Laihad \\ Bagian Anestesi Fakultas Kedokteran Universitas Sam Ratulangi Manado \\ Email: mllaihad@yahoo.co.id
}

\begin{abstract}
Definitive therapy of pheochromocytoma is a surgical resection. Anesthetic perioperative management toward pheochromocytoma resection plays a very important role in decreasing morbidity and mortality. This management includes preoperative preparations, intraoperative management and postoperative management. The preoperative preparations involving multidiscipline approaches have several objectives: controlling blood pressure, creating an adequate intravascular volume, assessing effects of the disease to end-organs, recognizing conditions pertaining to pheochromocytoma, and controlling blood glucose and electrolyte levels. The intraoperative management is a continuation of the preoperative preparations. Its main objective is to preclude the event of hypertension crisis. The postoperative management is aimed to anticipate important complications which possibly occur in the early postoperative period, such as: hypertension, hypotension, and hypoglycemia.
\end{abstract}

Keywords: pheochromocytoma, anesthesia, management, preoperative, intraoperative, postoperative

\begin{abstract}
Abstrak: Terapi definitif terhadap feokromositoma adalah reseksi. Penanganan perioperatif anestesi pada reseksi feokromositoma sangat berperan dalam menekan morbiditas dan mortalitas. Penanganan ini meliputi persiapan preoperatif, penangananan intraoperatif dan penanganan pasca bedah. Persiapan preoperatif dilakukan secara multidisiplin dan bertujuan untuk mengendalikan tekanan darah, mencukupi volum intravaskuler, menilai pengaruh penyakit terhadap end-organ, mengenali dampak dari kondisi-kondisi yang terkait dengan feokromositoma, serta normalisasi kadar glukosa dan elektrolit. Penanganan intraoperatif merupakan kesinambungan dari persiapan preoperatif dan bertujuan utama menghindari terjadinya krisis hipertensi. Penanganan pasca bedah bertujuan untuk mengantisipasi kemungkinan terjadinya komplikasi penting pada periode pasca bedah dini yakni hipertensi, hipotensi dan hipoglikemi.
\end{abstract}

Kata kunci: feokromositoma, anestesi, penanganan, preoperatif, intraoperatif, pasca bedah

World Health Organization mendefinisikan feokromositoma sebagai tumor pada medula adrenal, berkembang dari sel-sel kromafin yang berasal dari neuroblas pada neural crest yang menghasilkan katekolamin. Feokromositoma disebut juga paraganglioma intra-adrenal, sedangkan tumor-tumor terkait paraganglia ekstra-adrenal simpatetik yang juga memroduksi katekolamin diklasifikasikan sebagai paraganglioma ekstra- adrenal. Untuk penyederhanaan, istilah feokromositoma seringkali digunakan untuk merujuk tumor-tumor yang terletak di adrenal maupun ekstra-adrenal, karena tidak terdapat perbedaan bermakna dari segi gambaran klinis maupun penanganan anestesi. Penanganan perioperatif feokromositoma masih merupakan suatu tantangan yang rumit di bidang anestesi, yang membutuhkan persiapan preoperatif yang intensif serta 
penanganan dan perawatan intraoperatif dan pasca bedah yang cermat. Pasien dapat memperlihatkan beragam gejala yang mencerminkan sekresi katekolamin (norepinefrin, epinefrin, ataupun dopamin) berlebihan ke dalam sirkulasi. Pelepasan katekolamin menyebabkan hipertensi yang nyata, seringkali berat dan refrakter terhadap pengobatan konvensional. ${ }^{1-4}$

Meskipun terdapat perkembangan pesat dalam teknologi, pemantauan dan farmakologi yang terkini, namun penanganan perioperatif feokromositoma masih merupakan suatu keadaan yang sangat menegangkan untuk seorang ahli anestesi, apalagi pada keadaan-keadaan dimana tumor tidak terdiagnosis. Pasien yang terdiagnosis ketika induksi anestesi dapat mencetuskan suatu krisis hipertensi dengan mortalitas mendekati $80 \%$. Penanganan medis preoperatif yang tepat secara dramatis menurunkan morbiditas dan mortalitas selama penanganan pembedahan dari tumor ini. ${ }^{5-7}$

\section{PERSIAPAN PREOPERATIF}

Persiapan preoperatif haruslah dilakukan dalam suatu upaya bersama yang melibatkan ahli anestesi, ahli bedah, dan ahli penyakit dalam atau endokrinologi. Tujuan utama persiapan preoperatif adalah untuk menekan morbiditas dan mortalitas akibat sekresi katekolamin berlebihan yang dapat menyebabkan terjadinya krisis hipertensi. Keadaan ini dapat mengakibatkan perdarahan dan infark organ-organ vital, gagal jantung kongestif, disritmia jantung dan kematian. Beberapa hal yang harus menjadi perhatian dalam persiapan preoperatif adalah:,

1. Pengendalian tekanan darah yang meningkat.

2. Mencukupi volum intravaskuler.

3. Penilaian pengaruh penyakit terhadap end-organ (antara lain kardiomiopati).

4. Pengenalan dampak-dampak potensial dari kondisi yang terkait dengan feokromositoma (antara lain neoplasia endokrin multipel tipe II dan sindroma von Hippel-Lindau).

5. Normalisasi kadar glukosa dan elektrolit
Untuk suatu penilaian yang terperinci tentang status kardiovaskuler, dianjurkan untuk dilakukan pemeriksaan elektrokardiografi (EKG), X-foto dada dan ekokardiografi M-mode. Pemeriksaan EKG dapat mendeteksi adanya hipertrofi, aritmia, kardiomiopati, iskemia maupun infark jantung. Pada X-foto dada dapat diamati adanya kardiomegali maupun edema paru. Ekokardiografi M-mode harus digunakan untuk menilai disfungsi ventrikel kiri, mengevaluasi perbaikan setelah blokade adrenergik alfa, dan menentukan waktu yang optimal untuk pembedahan. Pemeriksaan darah lengkap dan hematokrit diikuti oleh pemantauan serial menyajikan suatu penilaian yang adekuat tentang ekspansi volum ketika blokade adrenergik alfa telah dimulai. Penilaian fungsi ginjal haruslah dilakukan melalui pemeriksaan biokimiawi seperti ureum, kreatinin dan elektrolit. Terapi insulin mungkin dibutuhkan bila terdapat hiperglikemia. Selain itu bila terdapat hiperkalsemia, adanya MEN tipe II harus dicurigai. $^{2,3}$

Krisis adrenergik menyebabkan terjadinya suatu situasi yang tak terkendali pada saat induksi anestesi, intubasi dan selama penanganan tumornya. Penanganan medis preoperatif yang tepat secara dramatis menurunkan morbiditas dan mortalitas selama penanganan operatif feokromositoma. Oleh karena itu penting untuk melakukan optimalisasi pasien preoperatif. Dalam 50 tahun terakhir sehubungan dengan reseksi ini terdapat penurunan mortalitas dari $40-60 \%$ menjadi $0.6 \%$. Plouin $\mathrm{dkk}^{9}$ (2001) melaporkan bahwa dengan penanganan perioperatif yang adekuat diperoleh mortalitas sebesar 2,4\% dan morbiditas 23,6\%. Kerjasama yang erat antara ahli kardiologi, endokrinologi, bedah dan anestesi sangat dibutuhkan untuk memperoleh suatu hasil akhir yang baik dan memuaskan., ${ }^{1,9}$

Persiapan preoperatif secara konvensional dilakukan dengan blokade adrenergik alfa dalam suatu periode 10-14 hari, selanjutnya penambahan blokade adrenergik beta dibutuhkan untuk mengatasi setiap kejadian takiaritmia. Umumnya para pasien dapat dipersiapkan dengan aman untuk pembedahan 
melalui penanganan rawat jalan. Blokade alfa biasanya dicapai dengan fenoksibenzamin oral $20 \mathrm{mg}$ tiga kali sehari, yang merupakan suatu agen penghambat adrenergik alfa yang non kompetitif dan non selektif. Pemberian fenoksibenzamin sebagai pencegahan tunggal dapat menurunkan mortalitas dari $43 \%$ menjadi $3 \%$. Golstein dkk melaporkan bahwa $69 \%$ pasien tanpa blokade alfa adrenergik mengalami komplikasi perioperatif, dibanding yang menggunakan blokade alfa adrenergik hanya $3 \%$.Obat ini juga memberikan efek ekspansi volum secara spontan, tetapi hal ini terjadi secara bertahap dan memerlukan waktu dua sampai tiga minggu. Waktu paruh fenoksibenzamin lebih dari 24 jam. Pemantauan tekanan darah non invasif harus dilakukan pada posisi baring dan berdiri selama pemberian terapi. ${ }^{3,6}$

Antagonis adrenergik alfa 1 yang kompetitif selektif menjadi pilihan oleh beberapa ahli anestesi karena tidak menyebabkan refleks takikardi, memiliki waktu kerja yang lebih singkat, dapat disesuaikan secara cepat sebelum pembedahan dan durasi terjadinya hipotensi pasca bedah berkurang. Roberts $\mathrm{dkk}^{2}$ menggunakan doxazosin pada masa preoperatif untuk 20 pasien dengan feokromositoma atau paraganglioma dengan dosis 2-8 mg sehari. Mereka mendapatkan bahwa tekanan darah preoperatif terkendali dengan baik seperti halnya dengan fenoksibenzamin. Antagonis adrenergik alfa 1 kompetitif selektif lainnya seperti prazosin juga dapat digunakan. Obat ini memiliki suatu waktu paruh eliminasi yang singkat (dua sampai tiga jam) dan membutuhkan pemberian dosis yang lebih sering dimulai dengan 1 mg tiga sampai empat kali sehari dan secara bertahap ditingkatkan sampai $12 \mathrm{mg}$ sehari. Konsentrasi dalam darah dapat berkurang menjadi kadar yang tidak efektif pada waktu pembedahan bila dosis terakhir diberikan saat malam sebelum pembedahan. Terazosin merupakan suatu alternatif serupa dari antagonis adrenergik alfa 1 selektif. Pilihan obat tergantung tidak hanya pada keinginan dokter tetapi juga berdasarkan ketersediaan dan keefektifan biaya. Apapun obat yang digunakan, penting untuk memulainya secara berhati-hati dengan dosis kecil dan meningkatkannya secara bertahap sampai terjadi hipotensi ortostatik yang mengindikasikan suatu blokade alfa yang adekuat. Meskipun telah dilakukan blokade alfa preoperatif, namun peningkatan tekanan darah masih dapat terjadi pada periode intraoperatif, khususnya selama manipulasi tumor. Selama blokade reseptor alfa, takikardi dan aritmia dapat terjadi akibat aktivitas reseptor beta yang terimbangi. Selain takikardi, efek samping lainnya adalah pusing, sinkop, kongesti hidung serta hipotensi orthostatik. Takikardi dan aritmia dapat dikendalikan secara hati-hati dengan menggunakan penghambat adrenergik beta. Blokade beta tidak seharusnya dilakukan sampai blokade adrenergik alfa telah nyata terjadi (biasanya dua hari setelah penghambat alfa diberikan), karena stimulai alfa yang tidak terimbangi dapat menyebabkan hipertensi berat. Perhatian juga diperlukan pada pasien-pasien dengan kardiomiopati yang mungkin mengalami edema paru akibat penghentian stimulasi beta. Jadi, blokade adrenergik beta harus dihindari pada pasien-pasien dengan kardiomiopati yang diinduksi oleh katekolamin karena dapat menyebabkan terjadinya hipotensi, bradikardi dan asystolic arrest. Antagonis adrenoseptor beta-1 selektif seperti atenolol (100 mg per hari) atau bisoprolol (10-20 mg per hari) seharusnya digunakan untuk meminimalkan efek-efek samping yang tidak diinginkan pada bronkus maupun vaskulatur perifer. Antagonis beta-1 nonselektif seperti propanolol (40-240 mg per hari) atau metoprolol (50-200 $\mathrm{mg}$ per hari) juga dapat digunakan tetapi harus secara hati-hati terutama pada pasien-pasien dengan riwayat penyakit jalan napas obstruktif ataupun penyakit vaskuler perifer., ${ }^{2,3}$

Penghambat-penghambat saluran kalsium juga telah digunakan pada periode preoperatif maupun intraoperatif untuk mengendalikan hemodinamik meskipun kurang efektif dibandingkan dengan penghambat alfa adrenergik. Sebagai contoh nifedipin $30-90 \mathrm{mg}$ per hari dan nikardipin $5 \mathrm{mg}$ per jam, ditingkatkan 2,5 mg per jam setiap 5 menit sampai suatu dosis maksimum $15 \mathrm{mg}$ 
per jam. Obat-obat ini menghambat influks kalsium ke dalam otot polos vaskuler yang diperantarai oleh norepinefrin; dengan demikian dapat mengendalikan hipertensi dan takiaritmia. Terdapat tiga peran utama penghambat saluran kalsium pada feokromositoma: (1) sebagai suplemen penghambat adrenoseptor pada pasien-pasien dengan kontrol tekanan darah yang tidak adekuat, sehingga tidak memerlukan peningkatan dosis penghambat alfa adrenergik; (2) untuk menggantikan penghambat adrenoseptor pada pasien-pasien dengan efek-efek samping yang berat; dan (3) untuk mencegah hipotensi menetap yang diinduksi oleh penghambat adrenoseptor pada pasienpasien dengan hipertensi intermiten. Penghambat saluran kalsium tidak menyebabkan hipotensi ortostatik selama periode normotensif. Obat-obat ini juga dapat mencegah spasme koroner yang terkait dengan katekolamin; karena itu dapat bermanfaat saat feokromositoma disertai dengan vasospasme koroner. ${ }^{3}$

Meskipun labetalol beraktivitas antagonis terhadap reseptor alfa dan beta, namun tidak seharusnya digunakan sebagai pilihan utama untuk blokade adrenergik reseptor. Dengan labetalol, pemakainya diperhadapkan pada suatu rasio tetap dari aktivitas antagonistik reseptor alfa terhadap beta, yaitu sekitar 1:7 (bila diberikan secara oral), yang dapat mengakibatkan episode paradoks dari hipertensi bahkan krisis hipertensi. Perlu diperhatikan bahwa aktivitas antagonistik alfa terhadap beta setidaknya harus 1:4 untuk mencapai efek antihipertensi yang adekuat. Lebih lanjut lagi labetalol secara bermakna mengurangi pengambilan dari Imetaiodobenzylguanidine (MIBG) dan harus dihentikan sekitar dua minggu sebelum I-MIBG scintigraphy. ${ }^{2,3}$

Tidak terdapat banyak bukti yang mendukung penggunaan obat-obat antihipertensi lainnya pada penanganan preoperatif feokromositoma. Manfaat penggunaan penghambat ACE ataupun antagonis angiotensin II untuk hipertrofi ventrikular masih diragukan pada penanganan preoperatif feokromositoma, umumnya karena stimulus hipertensi (norepinefrin) biasanya kembali normal saat pembedahan. ${ }^{2}$

Alfa-metil-p-tirosin (AMPT)/metyrosine/demser) telah digunakan pada tahun 1960 untuk menghambat konversi tirosin menjadi dopa melalui penghambatan tirosin hidroksilase, sehingga mengurangi sintesis katekolamin sekitar 40-80\%. Obat ini sangat efektif namun penggunaannya dibatasi oleh tingginya insidens efek samping yaitu diare, sedasi, fatigue dan agitasi. ${ }^{2,9}$

Sedasi dan ansiolitik preoperatif yang lebih disukai adalah benzodiazepin. Selain itu penentraman hati oleh ahli anestesiologi juga akan mengurangi ansietas dan mencegah fluktuasi hemodinamik nyata yang terjadi segera pada periode preoperatif. Pasien seringkali mengalami hipertensi selama manipulasi pembedahan tumor meskipun blokade farmakologi telah lengkap. Oleh karena itu medikasi untuk blokade alfa dan beta harus dilanjutkan sampai hari pembedahan, terkecuali fenoksibenzamin yang harus dihentikan sehari sebelum pembedahan karena memiliki waktu paruh panjang dan dapat menyebabkan hipotensi pasca bedah. $^{1-3}$

Untuk penilaian suatu penanganan preoperatif feokromositoma yang adekuat, kriteria Roizen berikut ini harus dipenuhi dengan tujuan untuk mengurangi morbiditas dan mortalitas (sampai <3\%):

- Tekanan darah $<160 / 90 \mathrm{mmHg}$ selama 24 jam sebelum pembedahan.

- Hipotensi ortostatik, tapi tidak dengan tekanan darah $<80 / 45 \mathrm{mmHg}$.

- Tidak terdapat perubahan-perubahan segmen ST maupun gelombang $\mathrm{T}$ selama satu minggu sebelum pembedahan.

- Tidak terdapat lebih dari lima kali kontraksi ventrikel prematur per menit.

Pacak $^{3}$ menyatakan bahwa tujuan penanganan preoperatif adalah mencapai tekanan darah preoperatif $\leq 130 / 80 \mathrm{mmHg}$ pada keadaan duduk, sekitar $100 \mathrm{mmHg}$ tekanan sistolik sementara berdiri (tidak kurang dari 80/45 $\mathrm{mmHg}$ ), denyut jantung target sekitar 60-70 kali per menit sementara duduk dan 70-80 kali per menit sementara berdiri. Di institusi lain target 
tekanan darah bisa lebih rendah ataupun lebih tinggi, tergantung pada pengalaman institusional. Meskipun demikian rekomendasi menyangkut tekanan darah dan denyut jantung harus didukung oleh penelitianpenelitian nonsistematik observasional dan pengalaman perorangan, serta dibandingkan dengan penelitian-penelitian klinik prospektif yang layak. ${ }^{3}$

Pemakaian obat-obatan yang memprovokasi pelepasan katekolamin yang diproduksi oleh tumor atau mengganggu turnover katekolamin akan berakibat buruk, bahkan mematikan. Pelepasan norepinefrin dan epinefrin dapat diprovokasi oleh glukagon, steroid, histamin, angiotensin II dan vasopresin. Pengeluaran katekolamin dari vesikel-vesikel penyimpanan oleh aminamin simpatomimetik (tyramine pada keju, pisang, anggur, saus kecap, advokat, dan setiap bahan yang difermentasikan, diasapkan maupun ikan dan daging yang lama) diikuti oleh pelepasannya ke dalam sirkulasi merupakan contoh lain yang dapat memprovokasi feokromositoma secara farmakologi. Obat-obat yang digunakan pada pengobatan obesitas seperti phentermine, phendimentrazine, methamphetamine, dan phenylethylamin merupakan amin simpatomimetik dengan aksi langsung pada adrenoseptor. Penggunaan dekongestan hidung dengan formula yang mengandung efedrin, pseudoeferin, atau fenilpropanolamin dapat menyebabkan provokasi terhadap feokromositoma untuk melepaskan katekolamin. Obat-obat yang mengurangi reuptake norepinefrin seperti antidepresan trisiklik (amitriptilin, nortriptilin, edronax, duloxetine), penghambat monoamin oksidase (deprenyl) berkontribusi secara bermakna meningkatkan kadar norepinefrin terutama yang berasal dari terminal saraf simpatetik. Penghambat reuptake norepinefrin dapat mengganggu penyelidikan biokimiawi dan pencitraan melalui dua mekanisme: 1) menghambat pengambilan ${ }^{123} \mathrm{I}$ - dan ${ }^{131} \mathrm{I}$-MIBG dan obatobat pencitraan lainnya $\left({ }^{18} \mathrm{~F}\right.$-fluorodopamine) yang menggunakan transporter norepinefrin oleh sel tumor; dan 2) menghambat reuptake norepinefrin oleh transporter norepinefrin membran sel neuronal, sehingga menyebabkan peningkatan positif palsu norepinefrin dan metabolitnya (metanefrin). Linezolid, suatu antibiotik oxazolidinone baru, memiliki efek penghambatan terhadap monoamin oksidase. Antagonis reseptor dopamin seperti metoklopramide, klorpromazin, dan proklorperazine yang digunakan sebagai obat antipsikotik dan antiemetik, juga dapat memrovokasi pelepasan katekolamin dari feokromositoma. ${ }^{3,7}$

Untuk pasien pediatri tidak terdapat pertimbangan-pertimbangan khusus dalam persiapan preoperatif kecuali ketika diberikan AMPT/metyrosine. Kepada orang tua harus diberikan instruksi yang jelas untuk segera melaporkan ke dokter bila anak mereka mengalami gejala depresi dan ansietas setelah mengonsumsi obat tersebut. Pada kehamilan penggunaan penghambat alfa dan beta adrenergik tidak bermasalah, kecuali propanolol yang dilaporkan berhubungan dengan retardasi pertumbuhan intrauterin, bradikardi fetal dan hipoglikemi, serta kelahiran prematur. ${ }^{3}$

Di kebanyakan pusat-pusat kesehatan, pasien yang akan menjalani reseksi feokromositoma diinapkan sehari sebelum pembedahan. Pemberian cairan kristaloid dimulai pada malam sebelum pembedahan untuk menghasilkan ekspansi volum intravaskuler dan reduksi frekuensi dan beratnya hipotensi pasca bedah. ${ }^{3}$

Kinney $\mathrm{dkk}^{5}$ melakukan penelitian secara retrospektif dari catatan-catatan medis 143 pasien feokromositoma yang menjalani reseksi pada tahun 1983-1996. Mereka menyimpulkan beberapa faktor preoperatif yang dapat memprediksi terjadinya peristiwa-peristiwa yang tidak diinginkan selama periode intraoperatif. Faktor-faktor prediktor tersebut meliputi ukuran tumor $>6.9 \mathrm{~cm}$, peningkatan kadar vanillylmandelic acid (VMA) > $30 \mathrm{mg} / 24$ jam, peningakatan kadar metanefrin $>8,4 \mathrm{mg} / 24$ jam, norepinefrin $>685 \mu \mathrm{g} / 24$ jam dan epinefrin $>220$ $\mu \mathrm{g} / 24$.

Algoritme yang direkomendasikan untuk penanganan preoperatif pasien-pasien feokromositoma dapat terlihat pada Gambar $1 .^{3}$ 


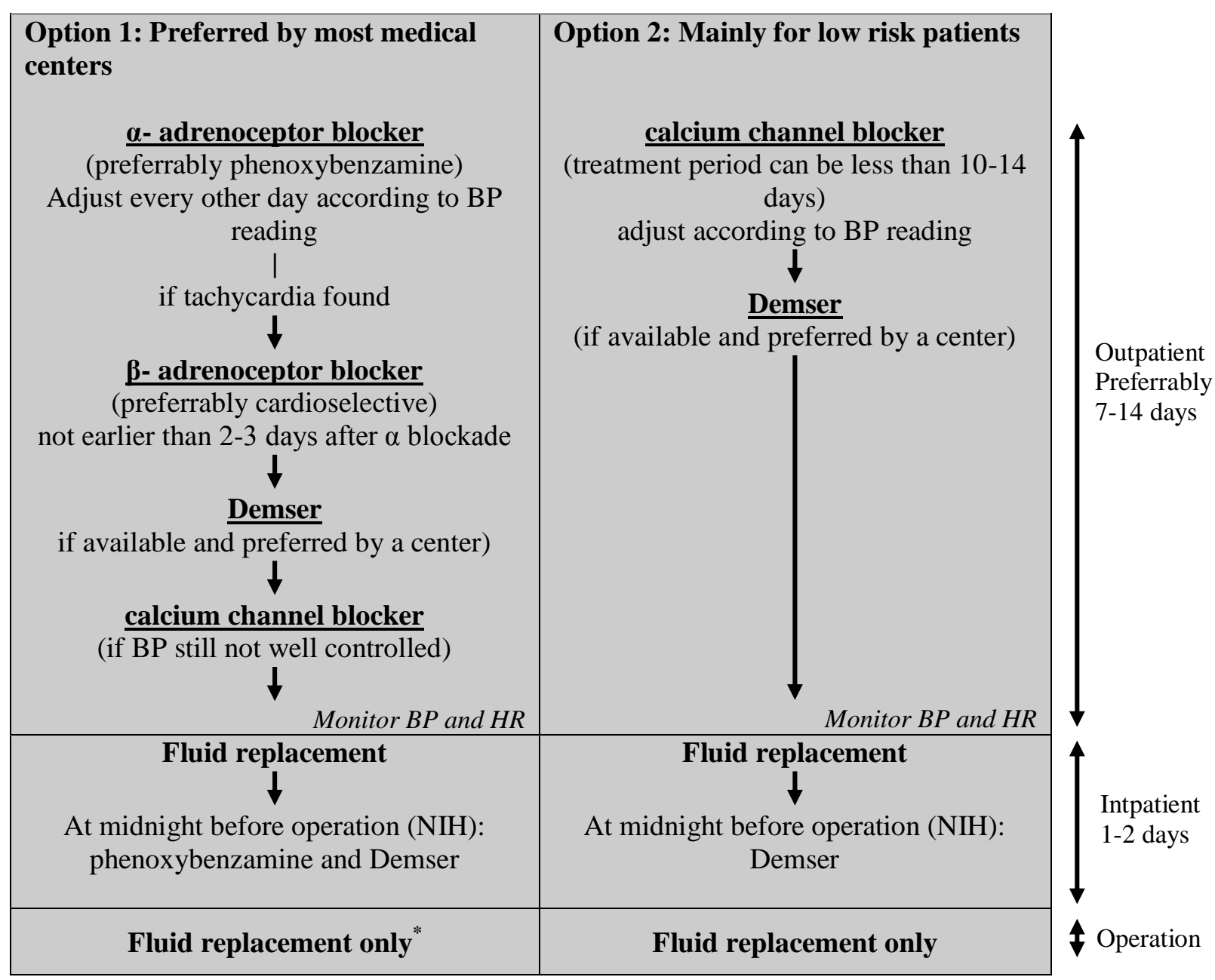

Gambar 1. Algoritme penanganan preoperatif yang direkomendasikan pada pasien-pasien dengan feokromositoma. BP, tekanan darah; HR, denyut jantung, *Bila penghambat $\alpha_{1}$-adrenoseptor yang digunakan, maka dapat diberikan satu dosis pada pagi hari sebelum pembedahan. Sumber: Pacak, $2007 .^{3}$

\section{PENANGANAN INTRAOPERATIF}

Penanganan intraoperatif merupakan suatu kesinambungan dari penanganan preoperatif. Seperti halnya penanganan preoperatif, penanganan intraoperatif juga bertujuan utama untuk menghindari terjadinya krisis hipertensi yang dapat mengakibatkan perdarahan dan infark organorgan vital, gagal jantung kongestif, disritmia jantung, dan bahkan kematian. Penanganan anestesi dan pemantauan untuk pembedahan feokromositoma dan paraganglionoma tergantung pada beberapa cakupan pendekatan pembedahan. Adrenelektomi untuk feokromositoma secara tradisional telah dilakukan dengan pembedahan retroperitoneal lateral terbuka; meskipun demikian suatu pendekatan transabdominal mungkin diperlukan pada beberapa kasus. Dewasa ini, eksisi transperitoneal laparoskopik feokromositoma telah dapat dilakukan. Laparoskopi adrenelektomi dapat dilakukan dengan aman untuk eksisi tumor berukuran $<7 \mathrm{~cm}$. Pembedahan terbuka biasanya lebih cepat, namun pasien akan membutuhkan masa inap yang lebih lama. Pada keadaan dimana tidak didapatkan komplikasi akibat blokade adrenergik persisten, pasien dapat keluar dari rumah sakit 36-48 jam setelah pembedahan laparoskopi. Lokalisasi tumor yang lebih akurat disertai modalitas diagnosis yang ada dapat meluangkan pendekatan pembedahan selektif yang tampak pada laparoskopi. Hasil penelitian-penelitian memperlihatkan bahwa nilai-nilai hemodinamik intraoperatif selama 
pembedahan laparoskopi sebanding dengan pembedahan tradisional. Komunikasi yang erat antara ahli bedah dan anestesi sangat penting untuk keberhasilan penanganan intraoperatif pasien yang menjalani reseksi feokromositoma. Diskusi pada periode preoperatif untuk mengantisipasi masalah-masalah intraoperatif merupakan tindakan yang penting dan menuntun ahli anestesi dalam membuat persiapan yang adekuat untuk penanganan anestetik. ${ }^{2,7}$

Berbagai teknik anestesi telah berhasil digunakan untuk reseksi feokromositoma. Anestesi regional digunakan secara tersendiri atau dikombinasikan dengan anestesi umum. Roberts ${ }^{2}$ menyarankan suatu teknik anestesi rasional yang praktis, terdiri dari kombinasi epidural torakal tengah sampai bawah dan anestesi umum yang adekuat, serta antagonis adrenergik selektif untuk mengendalikan gejolak-gejolak hemodinamik sebagai respons terhadap manipulasi tumor. Banyak obat telah disarankan untuk mengendalikan gejolak-gejolak hemodinamik intraoperatif, tetapi pilihan obat khususnya di negara berkembang sangat tergantung pada ketersediaan obat disamping kebutuhan pasien. ${ }^{1,2}$

Penanganan perioperatif feokromositoma masih merupakan suatu tantangan dalam bidang anestesi bahkan di pusat-pusat pelayanan yang terbaik sekalipun, dan mengharuskan keterlibatan ahli bedah dan anestesi yang berpengalaman. Pasien harus ditransfer secara berhati-hati ke dalam ruang operasi untuk menghindari setiap ketegangan yang dapat memicu pelepasan katekolamin. Setelah dihubungkan dengan monitor EKG dan oksimeter nadi serta menilai tekanan darah secara non invasif, kateter vena sentral dan arteri untuk pemantauan hemodinamik harus dipasang dengan menggunakan anestesi lokal. Hal ini dapat dicapai dengan menggunakan suatu teknik secara berhati-hati dan senantiasa berupaya menenangkan pasien sehingga dapat diperoleh identifikasi segera dari fluktuasi hemodinamik selama induksi dan rumatan anestesi serta manipulasi pembedahan tumor; dan juga menuntun intervensi farmakologik. Bila pasien terlihat cemas maka kateter vena sentral dapat dipasang segera setelah induksi. Kateter arteri pulmoner bukan merupakan suatu keperluan yang absolut tetapi harus dipersiapkan untuk pasienpasien dengan disfungsi ventrikel kiri yang berat dan gangguan kardiovaskular preoperatif. Pemantauan rutin harus mencakup EKG, kapnografi, konsentrasi oksigen yang diinspirasi $\left(\mathrm{FiO}_{2}\right)$, oksimeter nadi, blokade neuromuskular, temperatur dan produksi urin. ${ }^{1}$

Dua kateter intravena ukuran besar harus dipasang. Satu diantaranya sebelum induksi dengan menggunakan anestesi lokal untuk pemberian obat-obatan dan cairan. Pasien kemudian dapat diposisikan secara hati-hati untuk insersi kateter epidural pada level T10-11 sampai T12-L1. Ada juga yang melakukan insersi kateter epidural sebelum induksi anestesi. Epidural dapat digunakan untuk analgesia intraoperatif dan pasca bedah. Opiat intravena seperti fentanil dapat digunakan intraoperatif dan pemberian bolus epidural diikuti oleh infus kontinyu dapat digunakan untuk analgesia pasca bedah.

Setelah memulai pemantauan dan preoksigenasi, anestesi dimulai dengan induksi propofol 1-2 $\mathrm{mg} / \mathrm{kg}$ dan fentanil 2-5 $\mathrm{mcg} / \mathrm{kg}$. Thiopentone telah digunakan secara luas tanpa adanya efek yang merugikan, tetapi dapat menyebabkan pelepasan histamin yang harus dihindari pada pasienpasien ini. Etomidat memberikan stabilitas kardiovaskuler tetapi menyebabkan nyeri pada saat injeksi dan pergerakan involunter yang tidak diinginkan. Ketamin tidak digunakan karena menyebabkan peningkatan katekolamin secara tidak langsung. Midazolam dapat digunakan untuk memfasilitasi ko-induksi. Opiat-opiat lainnya seperti alfentanil ataupun sufentanil juga dapat digunakan untuk menggantikan fentanil. Infus remifentanil juga telah digunakan dan memperlihatkan hasil-hasil yang baik serta dapat dipertimbangkan bila tersedia dan memungkinkan dari segi biaya. Morfin dapat menyebabkan pelepasan histamin sehingga dihindari penggunaannya, walaupun terdapat laporan tentang keamanan penggunaannya pada pasien feokromositoma. Demikian 
pula dengan penggunaan kokain yang menyebabkan rangsangan simpatis harus dihindari. ${ }^{1-3}$

Setelah induksi dapat diberikan obatobat pelumpuh otot. Suxamethonium telah berhasil digunakan untuk rapid sequence induction pada seorang wanita hamil dengan feokromositoma yang menjalani seksio sesarea menggunakan anestesi umum, tetapi sebaiknya dihindari karena fasikulasi otot yang ditimbulkannya dapat menekan tumor secara mekanik. Atrakurium dan mivakurium diketahui dapat menyebabkan pelepasan histamin. Prys-Roberts ${ }^{3}$ telah menggunakan atrakurim secara reguler untuk pasien dengan feokromositoma sejak tahun 1984 tanpa adanya efek-efek yang tidak diingini. Vekuronium, rokuronium dan cisatrakurium telah diperlihatkan menyebabkan stabilitas kardiovaskuler dan pelepasan histamin yang sangat kurang serta nampaknya merupakan obat-obat yang sesuai untuk tujuan ini. Pankuronium dapat menyebabkan peningkatan kadar katekolamin secara tidak langsung sehingga harus dihindari penggunaannya. Demikian pula dengan kurare yang dapat mencetuskan pelepasan histamin. Namun terdapat laporan-laporan klinik tentang penggunaan kedua jenis obat tersebut secara aman pada pasien feokromositoma. Pemberian satu bolus lidokain intravena (1-2 mg/kg) sebelum intubasi dapat melemahkan respons yang diinduksi katekolamin, termasuk disritmia jantung. ${ }^{2-4}$

Rumatan anestesi dengan menggunakan isofluran 1-2\% dalam suatu campuran udara-oksigen dengan $\mathrm{FiO}_{2}$ sekitar 0,5. Isofluran lebih dipilih karena tidak seperti halnya halotan, obat ini tidak menyebabkan sensitisasi miokardium terhadap katekolamin. Sevofluran juga telah digunakan dengan berhasil, tergantung pada ketersediaan dan masalah ekonomi. Ambilan dan eliminasinya yang cepat memungkinkan pengendalian kedalaman anestesi dan hemodinamik yang lebih mudah. Sekarang ini keamanan desflurane juga telah dikemukakan. Obat inhalasi ini efektif dalam mengendalikan lonjakan hipertensi pada pasienpasien yang telah dipersiapkan dengan baik, meskipun diketahui menyebabkan stimulasi simpatetik. Nitrous oksida juga tidak dikontraindikasikan dan dapat ditambahkan bila diinginkan. Obat pelumpuh otot yang diberikan secara bolus maupun infus digunakan untuk mempertahankan kondisi pembedahan yang baik. ${ }^{1,7}$

Bila infus epidural digunakan intraoperatif, dosis lanjutan fentanil ataupun opiat lainnya tidak lagi dibutuhkan. Untuk mencapai analgesia intraoperatif dan pasca bedah yang adekuat dengan epidural, infus bupivakain $0,1-0,125 \%$ dengan fentanil 2 $\mathrm{mcg} / \mathrm{ml}$ dengan kecepatan 6-12 $\mathrm{ml}$ per jam diberikan setelah satu bolus awal 8-10 ml bupivakain $0,25 \%{ }^{1}$

Untuk pemulihan efek pelumpuh otot digunakan kombinasi neostigmin dan glycopyrolate, karena takikardi yang dikaitkan dengan atropin bisa mengakibatkan suatu lonjakan hipertensif. Keputusan untuk melakukan pemulihan blokade neuromuskuler pada akhir pembedahan atau merencanakan ventilasi pasien di Intensive Care Unit (ICU) sampai dicapai stabilitas tergantung pada keadaan pasien preoperatif dan perjalanannya intraoperatif. Bahkan bila dilakukan ekstubasi pada akhir pembedahan, pasien tetap di rawat di ICU atau high dependency unit setidaknya selama 24 jam pertama dan dimonitor secara ketat untuk kemungkinan ketidakstabilan hemodinamiknya. ${ }^{1,7}$

Manipulasi tumor dapat menyebabkan suatu respons hemodinamik yang bermakna; tekanan darah sistolik maupun diastolik dapat meningkat dengan cepat. Sodium nitroprusid (SNP), fentolamin, prasozin, nitrogliserin dan berbagai obat lainnya seperti magnesium sulfat, nikardipine, diltiazem, esmolol telah digunakan untuk mengendalikan peningkatan tekanan darah intraoperatif (Tabel 1). Beberapa ahli lebih menyukai sodium nitroprusid karena merupakan suatu arterio-venodilator yang poten dengan aksi yang cepat dan singkat, serta digunakan dengan cara infus intravena yang dititrasi (sekitar $0,5 \mathrm{mcg} / \mathrm{kg} / \mathrm{menit}$ ). Cyanide dosis kecil tidak bermasalah toksisitas. Nitrogliserin intravena juga dapat digunakan untuk tujuan ini. Obat ini mempunyai onset dan durasi yang cepat (serupa dengan SNP) 
Tabel 1. Obat-obat preoperatif dan intraoperatif yang digunakan pada reseksi feokromositoma untuk mengendalikan respons terhadap katekolamin. ${ }^{4}$

\begin{tabular}{|c|c|c|}
\hline Obat & Dosis & Indikasi \\
\hline Fentolamin & $\begin{array}{l}2,5-5 \mathrm{mg} \text { IV kecepatan } 1 \mathrm{mg} / \mathrm{mnt} \text {, ulangi tiap } 5 \\
\text { menit sampai tekanan darah terkontrol. } \\
\text { Infus konstan, } 100 \mathrm{mg} / 500 \mathrm{ml} \text { D5W sampai } \\
\text { tercapai tekanan darah yang diinginkan. }\end{array}$ & $\begin{array}{l}\text { Penanganan krisis hipertensi } \\
\text { akut }\end{array}$ \\
\hline Nitroprusid & $\begin{array}{l}0,5-10 \mathrm{mcg} / \mathrm{kg} / \mathrm{mnt} \mathrm{IV} \text {, sampai tercapai tekanan } \\
\text { darah yang diinginkan }\end{array}$ & $\begin{array}{l}\text { Penanganan episode hipertensi } \\
\text { akut }\end{array}$ \\
\hline Nitrogliserin & $\begin{array}{l}0,5-10 \mathrm{mcg} / \mathrm{kg} / \mathrm{mnt} \mathrm{IV} \text {, sampai tercapai tekanan } \\
\text { darah yang di inginkan }\end{array}$ & $\begin{array}{l}\text { Penanganan episode hipertensi } \\
\text { akut }\end{array}$ \\
\hline Doksazosin & $2-16 \mathrm{mg} / \mathrm{hari}$ oral & Persiapan preoperatif \\
\hline Penyekat $-\beta$ & $\begin{array}{l}\text { Atenolol, metoprolol, propanolol, esmolol, } \\
\text { labetalol, dosis dititrasi sampai tercapai efek yang } \\
\text { diinginkan }\end{array}$ & $\begin{array}{l}\text { Hanya digunakan preoperatif } \\
\text { setelah } \alpha \text { - adrenergik terhambat } \\
\text { sempurna. } \\
\text { Digunakan intraoperatif untuk } \\
\text { penanganan episode hipertensi } \\
\text { akut atau takikardi }\end{array}$ \\
\hline Fenoksibenzamin & $\begin{array}{l}20-30 \mathrm{mg} / \mathrm{hari} \text { dosis awal, dapat ditingkatkan } 60- \\
250 \mathrm{mg} / \mathrm{hari}(1 \mathrm{mg} / \mathrm{kg} / \mathrm{hari} \text { dibagi dalam tiga dosis) } \\
\text { sampai tercapai tekanan darah yang diinginkan }\end{array}$ & $\begin{array}{l}\text { Persiapan preoperasi dapat dica- } \\
\text { pai dalam 10-14 hari. } \\
\text { Digunakan untuk mencegah } \\
\text { krisis hipertensi }\end{array}$ \\
\hline Nikardipin & $\begin{array}{l}20-60 \mathrm{mg} / \mathrm{hari} \text { dalam tiga dosis terbagi, oral. } \\
0,5-10 \mathrm{mcg} / \mathrm{kg} / \mathrm{mnt} \mathrm{IV} \text { sampai tercapai tekanan } \\
\text { darah yang diinginkan atau } 1-2 \mathrm{mg} \text { IV bolus. }\end{array}$ & $\begin{array}{l}\text { Persiapan preoperatif dan kon- } \\
\text { trol hemodinamik intraoperatif }\end{array}$ \\
\hline $\mathrm{MgSO} 4$ & $\begin{array}{l}2-4 \mathrm{~g} \text { IV bolus } \\
1-2 \mathrm{~g} / \mathrm{jam} \text { infus IV }\end{array}$ & $\begin{array}{l}\text { Kontrol krisis hipertensi pre- } \\
\text { operatif, kontrol hemodinamik } \\
\text { intraoperatif }\end{array}$ \\
\hline Fenoldopam & $0,02-0,1 \mathrm{mcg} / \mathrm{kg} / \mathrm{mnt}$ infus IV & $\begin{array}{l}\text { Kontrol hemodinamik intra- } \\
\text { operatif }\end{array}$ \\
\hline Urapidil & $10-15 \mathrm{mg} / \mathrm{jam}$ infus IV & $\begin{array}{l}\text { Persiapan preoperatif dan kon- } \\
\text { trol hemodinamik intraoperatif }\end{array}$ \\
\hline $\begin{array}{l}\text { A-metil- } \\
\text { paratirosin }\end{array}$ & $\begin{array}{l}\text { Mulai } 250 \mathrm{mg} \text { oral empat kali sehari ditingkatkan } \\
\text { sampai makasimum } 4 \mathrm{gr} / \mathrm{hr} \text {. }\end{array}$ & $\begin{array}{l}\text { Pengurangan cadangan kate- } \\
\text { kolamin preoperatif dengan } \\
\text { menghambat sintetis kate- } \\
\text { kolamin pada tingkat enzim. } \\
\text { Efek maksimum dalam } 2-3 \text { hari, } \\
\text { dimulai } 7-14 \text { hari preoperatif }\end{array}$ \\
\hline
\end{tabular}

dan terutama mempengaruhi pembuluh darah vena. Obat penghambat adrenergik alfa kompetitif juga telah digunakan intraoperatif sebagai infus atau dengan incremental dose 1-2 mg untuk mengendalikan krisis hipertensi akut karena memiliki aksi cepat dan waktu paruh singkat. Obat ini dikaitkan dengan takikardi namun pada pasien-pasien yang juga menerima antagonis adrenergik beta efek tersebut tidak tampak. ${ }^{2-4}$

Penggunaan antagonis adrenergik beta intraoperatif dapat menolong pengendalian takikardi dan takiaritmia. Esmolol memiliki efek-efek hemodinamik yang secara khusus sesuai untuk penanganan feokromositoma intraoperatif. Efeknya yang cepat dan durasi yang singkat membuat obat ini mudah untuk dititrasi, baik untuk mengendalikan denyut jantung maupun tekanan darah. Beberapa ahli juga telah menggunakan metoprolol 1-2 $\mathrm{mg}$ intra vena dalam bolus intraoperatif dengan hasil yang baik. ${ }^{1-3}$

Magnesium sulfat menghambat pelepasan katekolamin dari sel-sel kromafin pada medula adrenal maupun ujung saraf 
adrenergik serta mengubah respons reseptor adrenergik. James ${ }^{12}$ mengemukakan suatu seri 17 pasien yang pengendalian hemodinamik intraoperatifnya dicapai dengan dosis awal 40-60 mg/kg diikuti infus $1-2 \mathrm{~g}$ per jam (Tabel 1). Magnesium sulfat secara khusus berguna dalam mengendalikan hemodinamik pada pasien-pasien feokromositoma yang gagal dengan pengobatan konvensional. James $\mathrm{dkk}^{12}$ mengombinasikan magnesium sulfat dengan obat konvensional dalam mengendalikan krisis feokromositoma. Infus intraoperatif magnesium sulfat telah digunakan dengan sukses dalam penanganan feokromositoma pada kehamilan. Dosis-dosis tambahan magnesium sulfat dibutuhkan untuk semua pasien pada saat dilakukan manipulasi tumor. Penghambat saluran kalsium misalnya nifedipin dan nikardipin juga telah digunakan untuk pengendalian hemodinamik intraoperatif. ${ }^{1,11,12}$

Sampai saat ini masih sulit untuk memberikan tanggapan terhadap medikasi terbaik yang dapat digunakan untuk pengendalian hemodinamik selama reseksi feokromositoma. Hal ini disebabkan karena ketidakmungkinnya untuk melakukan percobaan-percobaan dengan rancangan teracak akibat kurangnya kasus ini. Telah disarankan untuk para ahli anestesi agar berpegang pada kelaziman mereka akan obat-obat maupun metode tertentu. Pada negara berkembang, ketersediaan dan kemampuan juga menjadi pertimbangan utama.,

Setelah vena adrenal diligasi, bisa terdapat suatu penurunan kadar katekolamin dalam sirkulasi secara mendadak yang dapat menyebabkan terjadinya hipotensi. Pada saat ini obat-obat vasodilator dan penghambat adrenergik harus dihentikan dan diberikan satu bolus cairan. Dilakukan pengawasan intensif terhadap kehilangan darah, dan pemberian darah bila diperlukan. Infus vasopresor seperti norepinefrin atau fenilefrin mungkin dibutuhkan sewaktu-waktu. ${ }^{2,7}$

\section{PENANGANAN PASCA BEDAH}

Terdapat tiga komplikasi penting yang paling sering dijumpai pada periode pasca bedah dini, yaitu hipertensi, hipotensi dan hipoglikemi.

Sekitar $50 \%$ pasien tetap mengalami hipertensi selama beberapa hari. Hal ini umumnya berkaitan dengan peningkatan kadar katekolamin yang tersimpan di ujung saraf adrenergik, yang menetap selama satu minggu setelah reseksi feokromositoma. Oleh karena itu untuk memulai kembali ataupun melanjutkan medikasi antihipertensi mungkin masih dibutuhkan selama beberapa hari. Adanya tumor residual harus dipertimbangkan pada kasus-kasus dengan hipertensi persisten lebih dari seminggu, dan kadar katekolamin harus diperiksa secara berulang.

Hipotensi persisten mungkin dapat terjadi akibat efek residual dari blokade adrenergik yang diberikan preoperatif dan/atau fatigue persisten (vasoplegi) dari mekanisme vasokonstriktor. Ketika katekolamin yang berlebihan menghilang setelah pengangkatan tumor, respons vaskuler untuk mempertahankan tekanan menjadi lemah. Namun dalam hal ini perlu juga dicurigai adanya perdarahan intra-abdomen. Pada keadaan hipotensi, perlu diberikan cairan untuk menormalkan status volum, dan transfusi darah bila terjadi perdarahan intra-abdomen. Setelah tercapainya normovolemia namun pasien masih dalam keadaan hipotensi, dapat diberikan vasopresor bila perlu. ${ }^{2,7,10}$

Setelah pengangkatan tumor, supresi sel beta pankreas tidak terjadi lagi. Kadar insulin bisa meningkat dan menyebabkan hipoglikemia. Lipolisis dan glikogenolisis juga menghilang akibat pengangkatan tumor dan blokade alfa. Perlu diingat bahwa ensefalopati dan blokade adrenergik residual dapat mengaburkan tanda-tanda dan gejalagejala hipoglikemia. Karena itu kadar glukosa darah harus dipantau pada periode perioperatif. Selain itu cairan intravena yang mengandung glukosa harus diberikan setelah pengangkatan tumor. ${ }^{2,7}$

Penanganan perioperatif yang optimal serta kerjasama yang baik antara ahli bedah, anestesia dan penyakit dalam/endokrinologi berperan penting dalam menurunkan morbiditas dan mortalitas pasien dengan feokromositoma. 


\section{SIMPULAN}

Sampai saat ini reseksi masih merupakan terapi definitif pada feokromositoma. Walaupun mortalitas perioperatif telah berkurang secara nyata dewasa ini, penanganan anestesi pada pasien-pasien yang menjalani reseksi masih tetap merupakan suatu tantangan, bahkan bagi ahli anestesi yang telah berpengalaman. Pengendalian hipertensi preoperatif dengan penghambat adrenergik alfa, diikuti oleh penghambat adrenergik beta bila diperlukan, serta ekspansi volum yang adekuat merupakan hal-hal penting yang sangat berperan untuk mengurangi morbiditas dan mortalitas yang terkait pembedahan ini. Berbagai teknik dan medikasi anestesi serta kombinasi obat-obat vasodilatasi dan antihipertensi telah digunakan intraoperatif selama reseksi feokromositoma dengan memberikan hasil yang baik. Penanganan pasca bedah yang intensif turut berperan penting dalam keberhasilan tindakan operasi. Dan sehubungan dengan rumitnya patofisiologi penyakit ini, penanganan anestesi harus disesuaikan dengan situasi masing-masing pasien, ditunjang oleh kerjasama tim yang telah berpengalaman (ahli anestesi, bedah dan penyakit dalam/endokrinologi).

\section{DAFTAR PUSTAKA}

1. Ahmed A. Perioperative management of pheochromocytoma: anaesthetic implication. J Pak Med Assoc. 2007;57:140-5.

2. PC Roberts. Pheochromocytoma-recent progress in its management. BJA. 2000; 85(1):44-57.

3. Pacak K. Preoperative management of the pheochromocytoma patient. J Clin Endocrinol Metab. 2007;92(11): 4069-79.
4. Peterfreund RA, Lee SL. Endocrine surgery and intraoperative management of endocrine conditions. In: Longnecker DE, Brown DL, Newman MF, Zapol WM, editors. Anesthesiology. New York:McGraw Hill, 2008; p.1433-6.

5. Kinney MAO. Perianesthetic risks and outcomes of pheochromocytoma and paraganglioma resection. Anesth Analg. 2000;91:1118-23.

6. Myklejord DJ. Undiagnosed pheochromocytoma: the anesthesiologist nightmare. Clin Med Res. 2004;2(1):59-62.

7. Kerr GE, Fontes ML. Pheocromocytomas. In: Yao FSF, editor. Anesthesiology: Problem-oriented Patient Management. Philadelphia: Lippincott Williams \& Wilkins, 2008;707-81.

8. John AD, Sieber FE. Evaluation of the patient with endocrine disease or diabetes mellitus. In: Longnecker DE, Brown DL, Newman MF, Zapol WM, editors. Anesthesiology. New York: McGraw Hill, 2008;181-4.

9. Plouin PF. Factors associated with perioperative morbidity and mortality in patiens with pheochromocytoma: analysis of 165 operations at a single center. $\mathbf{J}$ Clin Endocrinol Metab. 2001;86:1480-6.

10. Augoustides JG. Perioperative physiologic pertubations of pheochromocytoma: opportunities for integrated pharmacologic management of systemic vascular resistance [homepage on the internet]. Nodate [cited 2008 Oct 05]. Available from: http//www.usuhs.mil/ane/resident/ pbls/pheo.pdf

11. Dugas G. Pheochromocytoma and pregnancy: a case report and review of anesthetic management. Can J Anesth. 2004;51:134-8.

12. James MF, Cronje L. Pheochromocytoma crisis: the use of magnesium sulfate. Anest Analg. 2004;99:680-6. 